De vraag naar de internationale receptie van het Plakkaat is niet ondubbelzinnig te beantwoorden, zo blijkt uit de artikelen van Liesbeth Gevers over de diplomatieke erkenning van de noordelijke opstandelingen, Hugh Dunthorne over de rol ervan in het politieke debat in Engeland tot aan de Glorious Revolution, Hans Cools over de Italiaanse perceptie van de Nederlandse Opstand en ten slotte Stephen Lucas over de rol van het Plakkaat bij het tot stand komen van de Declaration of Independence. Deze artikelen stemmen daarin overeen dat het publiceren van het Plakkaat op zichzelf aan de status van de Republiek in internationaal verband eigenlijk niets had veranderd. Door het tegenstreven van Spanje kon de Republiek in diplomatiek opzicht tot het sluiten van het Bestand geen vuist maken. De receptie in Engeland werd natuurlijk meebepaald door de noodzaak de steun van Elisabeth voor de jonge Republiek te rechtvaardigen, een noodzaak die na het vertrek van Leicester weer kwam te vervallen. James I was kritisch, de koningsmoordenaars van zijn zoon waren perplex en de Glorious Revolution was een Hollandse in(ter)ventie. Toch geeft Dunthorne interessante voorbeelden van teksten waarin - in retrospect - het Plakkaat als symbool voor de Nederlandse vrije Republiek naar voren kwam, als grondslag voor de begerenswaardige Hollandse welvaart en daarmee als een van de inspiraties voor zowel de Commonwealth als de Glorious Revolution.

Helaas is er niet veel samenhang tussen de artikelen in deze bundel. Dat ligt grotendeels aan het ontbreken van een functionerende vraagstelling. Zo willen de redacteuren graag het belang van het Plakkaat over het voetlicht brengen, maar slagen ze er niet in de daartoe benodigde discursieve ruimte te structureren. Misschien was het document niet van belang, of lag het belang elders dan in de constitutionele grondlegging van de Republiek? Op de hem kenmerkende voorzichtige wijze geeft Simon Groenveld een overzicht van de soevereiniteitsdiscussie die E.H. Kossmann entameerde. Groenveld concludeert dat er gedurende de Opstand 'onder meer geen volledige consensus heerste aangaande het begrip soevereiniteit' (p.75) en er 'geen formele onafhankelijkheidsverklaring van de Nederlandse staat geweest is'. Het Plakkaat was slechts een episode in een lange geschiedenis van volhardend vasthouden aan de rechtmatigheid van de belangen van de jonge Republiek in een diplomatiek spel waar koningen en hun wisselende allianties de dienst uitmaakten. Anders dan bijvoorbeeld de Apologie van Willem van Oranje lijkt het Plakkaat van Verlating vooral van binnenlandse betekenis te zijn geweest, tot het moment dat de onafhankelijkheid van de Republiek tot de verbeelding begon te spreken in de loop van de zeventiende en achttiende eeuw. Of dat ook in de Arabische Lente het geval was, zoals Berendse suggereert, valt uiteraard te betwijfelen.

\section{Hans W. Blom}

Erasmus Universiteit Rotterdam en Universität Potsdam
$\mathrm{M}$ atthäus Schwarz (1497-1574) was de hoofdboekhouder van Jakob en Anton Fugger, de Zuid-Duitse handelsmagnaten en financiers van het Habsburgse huis met grote belangen in de productie en verkoop van koper en zilver. Schwarz maakte voor het hoofdkantoor van de firma in Augsburg een gedetailleerd overzicht van alle relevante commerciële en financiële informatie voor de meer dan vijftig plaatsen in Europa waar de Fuggers zaken deden. Hij baseerde zijn overzicht van wisselkoersen, maten en gewichten, prijzen en vrachtkosten op eigen waarnemingen, brieven van

\title{
NiEUWE TIJd
}

\section{Rechterhand van de Fuggers}

\author{
Ekkehard Westermann en Markus A. Denzel, \\ Das Kaufmannsnotizbuch des Matthäus \\ Schwarz aus Augsburg von 1548 (Franz Steiner \\ Verlag; Stuttgart 2011) 526p., ill., tbl., €81,95 \\ ISBN 9783515098991
}

correspondenten en eerder gepubliceerde Italiaanse koopmansboeken. Daarbij verwerkte Schwarz ook nog een aantal gegevens over de inkomsten en uitgaven van ertsmijnen en smeltovens in Oostenrijk en Hongarije in zijn overzicht.

De teksteditie van het koopmansboek door Ekkehard Westermann en Markus Denzel is voorbeeldig. Er is een heldere inleiding over de aard en oorsprong van de bron, een korte beschrijving van de belangrijkste personen die in het koopmansboek voorkomen (pp.30-43) en een bespreking van ruim 130 pagina's van de belangrijkste steden in het handelsnetwerk van 
de Fuggers, de plek die zij in het handelsbedrijf innamen, en de wisselkoersen, maten, gewichten en prijzen waarmee handelaren in deze plaatsen werkten. Jammer is alleen dat kaarten ontbreken om de reikwijdte van het handelsnetwerk en de locaties van het mijnbouwbedrijf goed zichtbaar te maken, maar daar staan dan wel weer een heldere annotatie, goede registers op persoons- en plaatsnamen en een samenvatting in maar liefst vier talen tegenover.

Voor een lezer die niet zelf de transcriptie van het koopmansboek wil napluizen zijn de beschrijvingen van de verschillende handelslocaties binnen het Fuggerimperium een uitstekend alternatief. In de bladzijden over de Nederlanden (pp.101-111) bijvoorbeeld, gebruiken Westermann en Denzel Schwarz' gegevens en inzichten uit de moderne literatuur om te tonen dat Antwerpen een sleutelrol speelde in het bedrijf van de Fuggers. Behalve de doorvoerhandel in edelmetalen en specerijen was de financiële markt van Antwerpen een onmisbaar steunpunt in hun betalingsverkeer en krediettransacties met de Habsburgse vorsten. De betekenis van Amsterdam stak daar schril bij af - de stad figureert in Schwarz' overzicht slechts als incidentele transporteur van handelswaar.

De vraag is wel of deze bronuitgave nieuwe inzichten in de handelsgeschiedenis van vroegmodern Europa biedt. De tekstbezorgers zelf erkennen dat de editie een bescheiden toevoeging is aan de zeer rijke historiografie over de Zuid-Duitse kooplieden in de zestiende eeuw. Ze waken ervoor een uitputtende geschiedenis van het mijnbouwbedrijf te schrijven en ook voor een uitgebreide biografie van de Fuggers verwijzen ze naar de bestaande literatuur. Wel gebruiken ze de bron om het grote belang van geldwissels in de internationale handel te benadrukken. De gedetailleerde aantekeningen van Schwarz over dit betalingsverkeer zonder baar geld laten inderdaad overtuigend zien hoe belangrijk wissels waren en hoe cruciaal financiële knooppunten als Lyon en Antwerpen waren voor het overmaken van grote sommen geld naar alle delen van Europa.

De belangrijkste claim van Denzel - de schrijver van de slotbeschouwing - is dat Schwarz' handleiding door de Fuggers gebruikt werd voor de onderbouwing van strategische ondernemerskeuzes. Daarmee keert hij terug naar een oud debat over het vermeende belang van de in Italië ontwikkelde dubbele boekhouding voor het vergroten van het inzicht van kooplieden in hun bedrijfsvoering. Zuid-Duitse handelshuizen als de Fuggers en Welsers zijn een interessante casus in die discussie omdat hun administratie niet op Italiaanse leest geschoeid was. Voor Duitse historici is het altijd belangrijk geweest om de moderniteit van het alternatieve Hoogduitse boekhouden te benadrukken en Denzel denkt met Schwarz' notities een nieuwe aanwijzing te hebben dat kooplieden hun administratie wel degelijk gebruikten voor het uitdenken, evalueren en bijstellen van hun bedrijfsstrategie.

Halverwege de jaren 1520 besloten de Fuggers zich terug te trekken uit de Hongaarse mijnbouw. Voor een soepele transitie zonder grote verliezen hadden ze volgens Denzel behoefte aan een gedetailleerd overzicht van prijzen, geldverkeer en goederenstromen in Europa. Schwarz zou deze informatie in zijn boek verzameld hebben. Inderdaad houden zijn aantekeningen verband met de keuzes die de Fuggers maakten, maar Schwarz' gegevens zijn veel te fragmentarisch om de basis te vormen voor beslissingen over de ondernemingsstrategie. Er zijn weliswaar incidentele overzichten van kosten en opbrengsten van de zilver- en kopermijnen maar het koopmansboek biedt geen inzicht in de kasstromen van het bedrijf, laat staan de gerealiseerde verkopingen, voorraden en inkopen. Denzels veronderstelling dat Schwarz met zijn bazen terugkeek en vooruitblikte is ongetwijfeld juist, maar zijn koopmansboek kan niet richtinggevend geweest zijn - dan zou het slecht met de Fuggers zijn afgelopen. Deze bedenkingen bij de geschetste functie van Schwarz' notities doet overigens niets af aan de hoge kwaliteit van de uitgave en het inzicht dat ze biedt in de hoogontwikkelde internationale zakenwereld van de zestiende eeuw.

\section{Oscar Gelderblom}

Universiteit Utrecht 